\title{
Contents
}

Acknowledgments ix

Introduction

Willow G. Mullins and Puja Batra-Wells 3

1 Folklore as a Networked Economy: Or, How a

Recently-Invented-but-Traditional Artifact Reveals the Way

Folkloric Production Has Always Worked

John Laudun 26

2 Branding Unibroue: Selling Québécois Folklore through Beer Julie M-A LeBlanc 47

3 Market Forces and Marketplace Economics at the Smithsonian Folklife Festival

Halle M. Butvin and James I. Deutsch

72

4 The Sweet Spot: An Epistemological Approach to the Economics of Sugarmaking in Vermont

$$
\text { Michael Lange } 92
$$

5 Where the Creel Boats Go: The Politics of Sustainable Fisheries in a Small Orkney Community

$$
\text { Christofer Johnson } 109
$$

6 The Economics of Curation and Representation: Dialogues in the Commemorative Landscape of Portsmouth, Ohio

Cassie Patterson

7 An Ordered Mess: Folk Narratives and Practices in a Chinese Hui Muslim Market 
8 Art/Work: Precarious Encounters and Vernacular Economic Remedies

$$
\text { Puja Batra-Wells } 174
$$

9 From Vision to Implementation: Clashing Values of Economic Idealism and Solvency in Twin Oaks Community, 1967-1979

$$
\text { Rabima Schwenkbeck } 194
$$

10 "Why the Sea Is Salty": Folktales as Sources of Grassroots Economics

$$
\text { Irene Sotiropoulou } 214
$$

11 What Would Hermes Do? A Jungian Perspective on the Triekster and Business Ethics

$$
\text { William A. Ashton } 234
$$

12 Folk Economies and the Artisan Workshop

$$
\text { Amy Shuman } 252
$$

13 Consuming Authenticities: An Economics of Folklorists

$$
\text { Willow G. Mullins } 271
$$

About the Authors

Index

$$
297
$$




\title{
Introduction
}

\author{
Willow G. Mullins and Puja Batra-Wells
}

FolkLore sells. Companies from Etsy to IKEA have capitalized on cultural associations with the idea of "folklore" - a term in marketing meant to evoke the traditional, the exotic, the esoteric, the local, and the handmade. Folklore sells small. It sells in the shops that specialize in the handmade, from one person to another. One can see folklore for sale in the popularity of the "buy local" and "Slow Food" movements, intent on keeping craft and food production locally based and preserving traditional networks. But folklore also sells big. It sells in the mass market from corporations with thousands of employees and is bought in big box stores or consumed through mass media. Television and film capitalize on references to fairy tales and myths, from wholesale remakes of well-known stories (think of the many iterations of "Snow White" [Aarne-Thompson-Uther Classification of Folk Tales no. $709^{1}$ ]) to new formulations of the tropes of urban legends and wonder tales to the "Folkloric Charm" promised by a Behr Paints color swatch. And who buys and sells all of this folklore? Who are the actors in the folklore marketplace? The folk, of course.

It is by now commonplace among folklorists that everyone has folklore, that people engage in the exchange and coproduction of unofficial, artistic cultural meaning (Ben-Amos 1971; Brunvand 1986). Economists have argued for just as long, however, that everyone engages in economics, which reflects how people navigate their decisions about resources and scarcity (American Economic Association 2017). This collection starts with the premise that folklore and the folk themselves are deeply and productively engaged in economics, and further, that the economic worlds in which we all live shape our cultures, our lives, and our identities. Put simply, the folk are in the marketplace.

Economics has always been folklore's not-so-silent partner. Folklorists have a long history of pondering the economics of the folk and their relationship to the marketplace; recently, the 2017 Nobel Prize in Economics was granted to the founders of behavioral economics, which takes into account the direct influence of culture and psychology on economic actions, 
suggesting the importance of folklore to economists. Yet folklore and economics as a subfield has largely remained unarticulated, in part because of the constructs and institutional histories of each field.

At this moment, trade, technology, and geopolitics have led to a rapid increase in the global spread of cultural products, including media, knowledge, objects, and folkways. Accompanying that globalization have come fears, realized and not, of cultural appropriation, neocolonialism, and loss. Culture operates as a resource and a currency in the global marketplace. This movement of people and forms necessitates a new textual consideration of how folklore and economics interweave. Here, we hope to explore how the marketplace and folklore itself have always been integrally linked in ways both productive and subversive, in theory and on the ground, and what that means at this global, cultural, and economic moment. In order to create a more concise disciplinary history of folklore and economics and to provide the institutional background against which the current work is set, in the sections that follow, this introduction offers a tracing of the genealogy that has helped formed the field of folklore and economics.

Folklorists' ideas about the relationship between folklore and economics have tended to occur along three primary trajectories. First, at the macrolevel, folklorists have relied on socioeconomic status as a marker of folk status as a way to bound or propel the field, and, in a Marxist turn, they have considered the role of class in the production of folklore, particularly through labor lore. Second, scholars have invoked microlevel understandings of commodity and commodification, particularly in the study of material culture. This perspective has helped folklorists assess the relationship between folk artists, folklorists, and audiences and how practices and art forms may be influenced by consumers. A third, more theoretical but still microeconomic line of thought, has built on Mikhail Bakhtin's conceptualization of the marketplace as a center of village life (1965). In the marketplace, critical inversions of social status become possible and folk performance can take place.

Each of these trajectories has influenced how folklorists have constructed the folk both in relation and opposition to the marketplace, but they tell a partial story. Like the stage set of a play, these trajectories provide a background against which the chapters that follow are set, and like a stage set, they both give context to these discussions and influence how we understand them. But also like a stage set, these three specific trajectories are offered as not a whole story but a backdrop, an evocation of how economics and folklore have been explored by those before. 


\section{MACROFOLKLORE: WHO ARE THE FOLK AND WHAT DO THEY DO?}

Macroeconomics focuses on larger issues of economic systems- the who and the what of folklore. Class, large-scale labor, and the relationships of folk groups to these structures have tended fall within the scope of the macro. These studies have looked at the big picture in an attempt to discern where folklore flourishes, where the folk fit in society, and how society itself is organized and creates products, be they the output of factories or the folklore of the people who work in them. As Roger Abrahams has argued, however, it matters who counts as folk in what political context, because those constructions help determine what later counts as lore $(1993,389)$. Thus, we include in this macroeconomic approach to folklore the Marxist turn in folkloristics and the study of labor lore. These works have framed their studies from a larger class-based paradigm that allows them to reveal important relationships between work, lore, and resistance.

The earliest generations of folklorists tended to construct the subject of their study as outside of, or even in direct opposition to, market concerns. From Andrew Lang's “peasant class" (2015) to William Newell's four categories of people possessing folklore, found in the first issue of the Journal of American Folklore and focused entirely on those identified as outside of industrialized Euro-American society, class status, ${ }^{2}$ or more precisely a lack thereof, has been understood as a criteria for folk status $(1888,3)$. In the earliest iteration of the term, the "folk" in folklore have been comprehended as residues of modernity — as anachronistic, illiterate people bound by their superstitions and irrational traditions, as "peasants and primitives" (Bauman 1992, 30-35).

This premise led to two instincts visible in the early scholarship of folklore. First, folklorists sought to salvage the vanishing "survivals" of authentic grassroots culture in the name of Romantic Nationalism and nostalgia. Folklore and its active bearers perhaps offered a refuge from the perceived stresses of the capitalist economy, and folk economies a potentially more holistic alternative to the homogeny of the industrial and mass produced. As Michael Taussig has argued, it can be difficult for a researcher to break out of the economic paradigm in which they themselves were raised, and precapitalist societies can "acquire the burden of having to satisfy our alienated longings for a lost Golden Age" $(1980,7)$. Second, folk production was ascribed to a lesser, imitative sphere, based on the argument that true folklore originated in the upper strata of society (cf. Naumann 1921). Many early collectors put folklore outside of modern modes of economic exchange by closely linking it with the domestic. The Grimms, for example, 
aligned folklore with women and the home, thus contrasting it to work and men, whose labor in the capitalist world made them less likely to possess folklore (Bendix 1997, 85). Both gestures, however, ultimately circumscribe the folk by relegating them to a subaltern class status.

The linking of the folk with precapitalism in the nineteenth century became more nuanced in the twentieth, as some researchers began to probe the class assumptions at work in this construction and ask how folk groups interacted with and resisted capitalist power structures (cf. Limón 1983). Marxist approaches to folklore studies arising in the first part of the twentieth century saw folklore's subject matter as offering potential for critique of the larger class system and capitalism itself (cf. Maurer 2006; Zinn 2015). Within this context, Antonio Gramsci's (1985) work on hegemony and the subaltern reoriented the structuring binary in folklore studies from traditional versus modern to dominant versus dominated (Crehan 2016). In a related theoretic shift in the Soviet bloc, beyond the formalist studies in the vein of Vladimir Propp (1968), the Marxist approach fostered an awareness of the burgeoning critical interventions in the study of developing nations as well as scholarship surrounding workers and working cultures (Tangherlini 1997).

As a class-oriented area of folklore developed, Western Marxism, following the theoretical trajectories of the Frankfurt School in particular, began to influence the discipline. Folklorists began to explore manifestations of cultural contestation, moments in which the folk resist or speak back to dominant ideological structures undergirded by capitalism. For example, the work of Américo Paredes challenged folklorists to more explicitly insert political imperatives into their praxis (1970). Similarly, José Limón argued in 1983 that folklorists could offer a critical reading of capitalism through folklore's context-oriented emphasis on performance. Limón noted the "inherently oppositional" qualities of folklore. He quotes Roger Abrahams that "all such performances may be displays of the possibility of hanging on to the use and value of things ... in the face of those who would turn all of life into acts of consumption" (2012, 107). Similarly, looking into another genre, fairy tale scholar Jack Zipes interrogated the ideological underpinnings of fairy tales and the commodity fetishism associated with their mass-mediated adaptations (1979).

Building on the Marxist tradition, Stephen Gencarella more recently recommended that folklorists engage further with the realities of daily economic life (2011). Utilizing Max Horkheimer's concept of critical theory as a response to "bourgeois and capitalist ideology," Gencarella's larger project of critical folklore studies rests on a repositioning of critical capacity, putting the ethnographer into conversation with "everyday critics" (2011, 257 
and 261). Interestingly, Gencarella and Limón both see the critical potential of folklore and the folk as a means to such understanding, but disagree with each other about the ends achieved by such interrogation. These Marxist critiques have provided much needed complexity to an understanding of how folklore and class intertwine. However, the danger remains that scholars focused on class may repeat a class-based bounding of the folk, this time in Marxist terms as the proletariat.

But folklorists are not only concerned with who counts as folk. If the folk were defined early on by where they resided in the socioeconomic system, then one way to identify the folk was to look to the common occupations associated with those lower classes. Studies of workers and labor cannot help but see the folkloric in the economic (cf. Green 1971, 1978, 1993, 2002). Workers' cultures were long perceived as a 'degenerated form of peasant and craft cultures, that had emerged in the course of industrialization since most industrial workers were recruited from rural milieus" (Koch 2012). The early period of work-related studies, as a result, focused heavily on rural groups and occupations because of the folkloristic bias toward survivals (McCarl 1996, 1997).

Fleming Hemmersam's 1985 overview of worker lore studies shows four distinct approaches to the subject (as cited in Green 1997, 600). The first is the classic folkloristic and ethnological approach, which maintains the "antiquarian's ideological commitment to a peasant model of work" (cf. Nickerson 1974 and Jones 1984; see Hemmersam 1985, as cited in Green 1997, 600). The second is bourgeois research of worker culture; these studies, as seen in the work of Richard Dorson and Hennig Cohen, maintain that the increasingly standardized forms of urban experience have diminished and risk extinguishing the distinctiveness of working-class cultures. The third approach is explicitly socialist or communist and hypothesizes that working cultures are entirely defined by their antagonism to capitalist modes of production. This approach has a rich history in Europe and is represented contemporaneously in the work of Anders Björklund and Gösta Arvastson. Finally, the empirical approach has produced extensive collections of cultural artifacts related to work with little attention to their "social or ideological context"-research typified by the work of Wayland Hand and Horace Beck (Hemmersam 1985, as cited in Green 1997, 600).

Writing from different political contexts, European and American folklorists took different approaches to worker lore. Whereas in Europe, the study of occupational cultures was equally invested in the analysis of "work culture and labor ideology," under the influence of E. P. Thompson, parallel scholarship in the United States tended to emphasize the aesthetic and 
culturally expressive forms of the workplace (stories, songs, skills, customs, jokes), with less accent on the socio-economic-political contexts of their emergence (McCarl 1996, 597). One exception that would presage studies to come is George Korson's work collecting the folkways and lore of Pennsylvania coal mine workers $(1927,1938)$. Korson's ethnography balances between the descriptive and the analytic, which included identifying ideologically characteristic forms that expose miners" "resistance to capitalist exploitation," foreshadowing Paredes (Korson 1927, 599). It was only in the 1960s under the stewardship of Archie Green that the field of folkloristics reformulated the study of occupational folklore to account for both workers' cultural practices and their political and ideological conditions, as can be seen in the work of Jack Santino and Paula Johnson (Hemmersam 1985, as cited in Green 1997, 601; Johnson 1988; Santino 1990).

The biggest shift in folkloristic research into work, however, occurred at the turn of the twenty-first century in response to the cultural and economic reorganizations resulting from globalization and the technology and service-oriented worker regimes that have arisen in post-Fordist labor ideologies. As Gertraud Koch (2012) argues, these moves toward political economies of work have aligned folklore with more sociological perspectives that emphasize organizational forms and the distribution of societal resources (cf. Boutang 2007; Sennett 2006). Barbara Ehrenreich's ethnographic work on service-sector workers, for example, reveals the pressures and indignities of ever-increasing precarization, describing those who work without guarantees in an era with a shrinking social net and neoliberal imperatives (2001). Studies of knowledge work similarly reveal the ways in which the increasing flexibility of labor through freelancing and short-term contracting have led workers to lean on " "creative bricolage of practices" which efface the lines between work and leisure times (See McRobbie 2004; Ross 2010).

Referencing the extant class structure and the worker cultures it creates has helped folklorists locate both folklore and the folk's relationship to economics. Doing so, however, many early folklorists created an inverse relationship between class and culture. But this class-structured approach and its tendency toward essentialisms have not gone unquestioned (cf. Bendix 1997, 25; Clifford 1988, 162; Rosaldo 1989, 202). Turning the critical lens towards expertise and connoisseurship, for example, scholars have questioned how such thinking reinscribed extant class distinctions by limiting who possessed the ability to tell the real from the fake, a major concern for folklorists such as Richard Dorson. This move allowed folklorists and their audiences to separate themselves from the folk whose lore they studied as a result of the elite ability to identify what constituted art, or in this case 
folklore (Bendix 1997, 157), ultimately, as theorist Pierre Bourdieu argues, "[legitimating] social differences" (1984, xxx). Further, feminism, postcolonial criticism, and the Civil Rights Movement among others have each spurred their own critiques (cf. Behar and Gordon 1996; Prahlad 1999; Said 1979; Visweswaran 1994).

Despite such criticism and even as the definition of the "folk" exploded to include "any two people sharing at least one thing in common" (Dundes 1980, 2), a brief survey of published articles in folklore journals suggests that most folklorists continue to link folk-ness with the working class or with materials somehow perceived as outside of or even in direct opposition to capitalism. Refugees, evacuees, prisoners, global indigenous, and ethnic Others still make up the bulk of the subjects of articles; notably lacking are the middle class and the suburban ${ }^{3}$ (cf, Ingram, Mullins, and Richardson 2019). Such a focus importantly does draw attention to folk groups who may otherwise be excluded from discourse through their alterity, but it might also create a gap by ignoring the economic relations and commentary between groups that Paredes and Limón sought to reveal.

The trajectory of macrofolklore has focused on the widest view, defining who the folk are within the larger class structure and using the overlay of class and occupation to further delineate what counts as folklore. Moving beyond early constructions, focusing on the macro level offers a way to reveal how folk groups participate in, respond to, and resist larger economic systems. Such a broad lens may be crucial in the current age of globalized capitalism. The macro shows how large economic networks can have impact for small, localized groups of people, and how those people can also send ripples of influence out into the globe.

\section{MICROFOLKLORE: FOLKLORE AS COMMODITY}

Despite this engagement with large-scale social structures and macrolevel positioning of the folk and folklore, folklorists have more generally focused their attention on the micro, the individuals and small communities who make up those larger societies and live in relationship to those structures. Approaching the economic in folklore, many of these studies have tended to center on how folk products, both tangible and intangible, made within one folk tradition are commodified, used, and sold sometimes to people from other cultural backgrounds. Folk art and material culture have seemed natural places for folklorists to address these economic concerns, with a clear object offered in a clear market transaction that cannot be evaded but can be narrated (cf. de Certeau 1984). While much of this debate has taken 
place within the context of material culture studies, as our discussion here is also situated, it has posed important questions that extend to other genres.

Objects, commodities, and artifacts are repositories of material and semiotic significance and articulate power relations between individuals, groups and society writ large. Put bluntly, the folk make things, sell and exchange things, and consume and circulate things. Folklore's relationship with commodity has long been characterized by a tension between the pros and cons of capitalism. Concern over commoditization, with the decontextualization it implies, and the ways in which the marketplace potentially reinscribes socioeconomic hierarchies are balanced against seeing both process and space as potentially generative and empowering.

One could argue that folklorists have always been aware of folklore's sales potential, from Perrault and the Grimms on, but it has only been over the course of time that the complexities of folklore's economic value have been explored. Yet folklore as commodity or as used for commercial ends was generally seen as problematic through the mid-twentieth century. The use of "mass-mediated" and "commodified" as a negative defining characteristic, what folklore is not, typifies much of the writing in folklore from the nineteenth century to the twenty-first. Richard Dorson, notably, roots his definition of "fake lore" in commoditization - as those tales which have been decontextualized, stripped of everything folklorists might care about, specifically for the purposes of turning lore into commodity (1976). Part of the issue may reside in the field's historical investment in associating the folk with lower socioeconomic status. If the folk may not be of high status, their lore must also not hold economic value. Commodification, by contrast, revalues cultural products, giving them monetary value where they once held primarily cultural value. The belief that commodification poses a threat to authentic folklore, however, plays into the salvage narrative inherited from early twentieth-century folklore collection and has shown some tenacity in the field, despite critique (cf. Becker 1998; Kirshenblatt-Gimblett 1998).

Early material culture study seems to have largely evaded the question of commodification by tending to focus more on the object itself at the moment of its creation and those in charge of that creation, the makers, than on what happens to the object after it left the maker's hands. While there has been interest in the conditions that shape an object's production, this interest for scholars has remained pertinent only insofar as those conditions speak to the "physical properties and specific history" of the objects themselves (Sheumaker and Wajda 2008). American material culture study in particular has long emphasized the materialization of folk thought in artifacts and environments with specific interest in exemplary forms of folk 
art, craftsmanship, and vernacular production (Bronner 1996; Glassie 1968; Vlach 1991; Vlach and Upton 1986). As Barbara Kirshenblatt-Gimblett has pointed out, however, the focus on the thing and the maker leaves out much of an object's meaning, including the economic (1989).

The rise of context-oriented ethnography in the 1970s (cf. Bauman and Paredes 1972) drew attention to the larger cultural ecology in which folklore was performed. This watershed moment acknowledged the transaction between performer and audience, as a result opening up folklore studies to the possibilities of consumption as a form of agency and expression, effectively rehabilitating the commodity (Appadurai 1986; Miller 2006). By the end of the century, folklorists, predominantly working in material culture, assumed that folk things were up for sale and sought to understand the effects of such commoditization on the artist and culture rather than fight against the sale. Notably, Michael Owen Jones's The Handmade Object and Its Maker (1975) and Charles Briggs's The Woodcarvers of Cordova, New Mexico (1980), while still focused on specific makers of folk art, stand among the first works to deal bluntly with the market pressures placed on folk artists by both out-group and in-group consumers.

The difficulty arises, as Barbara Babcock has pointed out, when folk products and the folk themselves become commoditized. Tourist studies helped to draw attention to this problem. Tourism necessarily throws cultures into close contact, but with differing goals and differing levels of investment in local sustainability. Tourism scholars-such as Nelson Graburn (1976), Dean MacCannell (11976] 1989), and John Urry (1990)—posited the tourist as a consumer, seeking in their touristic encounters those things they believe they lacked in modern life-the real, the natural, and the culturally marked. But these studies have tended to pay less attention to the reasons that a culture might choose to participate in touristic display. In many places, groups have made use of local identities and practices to celebrate their culture and push the local economy through tourism. Yet these touristic displays have caused tensions as well, as the ownership and responsibilities of public heritage come under debate (cf. Cantwell 1993; Guss 2001). Some of the most interesting of these conversations have also taken into account how folk groups bend to and manipulate economic pressures to further their art form to suit the group needs and the political moment (cf. Lee 2009).

In the 1980s and 1990s, these issues with cultural representation coupled with the crisis in ethnography (cf. Clifford and Marcus 1986) drew attention to the positionality of the ethnographer and the politics of cultural representation on a large scale. Addressing that issue of positionality, anthropologist Ruth Behar wrote in Translated Woman of her discomfort when the 
economic realities of her position relative to her informant Esperanza were brought home to her (1993). As they became aware of their own part in representation, folklorists complicated the discussion surrounding the commoditization of folklore and the folk themselves particularly in relation to festival and museum displays of folk culture (cf. Baron 2010; Bauman 1992; Cantwell 1993; Kirshenblatt-Gimblett 1998; Sommers 1995).

The brokerage model of folklore practice emerged to describe the role of folklorists working in cultural institutions as mediators, thus attempting to move away from what Deborah Root called the "necrophilic" tendencies of earlier museum display (cf. Appadurai 1986; Appadurai, Korom, and Mills 1991; Huyssen 1995; Karp 1991). Folklorists, such as Regina Bendix (1997), Frank Korom (see Appadurai, Korom, and Mills 1991; Korom 1999), and Richard Kurin (1997) employed economic metaphors for their work, positioning themselves and their institutions as brokers, mediating between the folk, who possessed culture, and the audience, who eame to see it. Kurin contrasted such brokerage with what he termed "extractive" and "flea market" models of cultural representation, thus very clearly equating cultural products with commodities $(1997,18-19)$.

Yet, the 1990s also saw a rise in scholarship that attempted to find another metaphor beyond commodity for its subject. In contrast to Kurin and Korom, Mary Hufford's collection Conserving Culture (1994) also acknowledged the economic realities of folklore work but positioned folklore as resource rather than commodity. Hufford shifted the metaphor from brokerage to sustainability, weaving together narratives and goals in economics, ecology, historic preservation, and folklore. The authors in Hufford's collection provided their own critique of the emerging brokerage model, noting that cultural representation as commodity risks reification, a concern eloquently described by Robert Cantwell in Ethnomimesis (1993) and Dorothy Noyes in her article "Group" (1995). Others, including Barre Toelken (1995) from an ethical perspective and Dell Hymes (2003) from a pragmatic one, wondered if all culture could or should be represented.

These material culture studies demonstrated a microeconomic sensibility, exploring how a maker within a culture allocated their resources in terms of time, money, cultural capital, and creativity. At the same time that folklorists began to write about the social and economic systems that commoditized the folk and folklore, they questioned the results of that commodification, finally placing the micro and macro into conversation. Taking both micro and macro together, folklorists have raised real concerns about how cultural products, material or otherwise, could be commodified and detached from their originating culture and how such detachment can 
adversely affect that that culture. These fears have led to the involvement of folklorists in groups such as World Intellectual Property Organization and UNESCO, aimed at protecting cultural property from unfair use in a capitalist marketplace (Honko 1988; Noyes 2015).

\section{THE FOLKLORIST IN THE MARKETPLACE: WHERE FOLKLORE HAPPENS}

Building on the assumption that the folk were already active in the marketplace, a third trajectory of economics and folklore has sought to describe the marketplace and economic transactions as part of folklife. The marketplace requires social interactions that are, by their nature, formulaic, but it also provides both literal and metaphoric space for artistic performance. Through these social interactions, people work out how they assign meaning and value; they negotiate how their lives intersect with others, culturally, materially, and economically.

In this reconfiguration of the marketplace, the works of cultural scholars such as Michael Owen Jones (1975), Charles Briggs (1980), and Babcock (1995) have proven crucial. Mikail Bakhtin posited the marketplace as a space for the negotiation of culture and tradition (1965). Weaving together Bakhtin's sense of conceptualization of the marketplace with performance theory, Deborah Kapchan's Gender on the Market uses the Moroccan marketplace as a field site for an investigation into women's folklore ([1996] 2010). However, unlike earlier studies, Kapchan describes the exchanges in that marketplace in folkloristic terms, as artistic, communicative, and traditional, marking the marketplace as a performative space.

While the marketplace may be space where internal cultural issues are worked out amidst the exchange of commodities, it has also been theorized as a cultural frontier, at the "crossing point between worlds" that bring together "marginalized outsiders and mobilized traders" (Abrahams n.d.). The marketplace is a contact zone and a space of hybridization and recontextualization (Pratt 1991). And it can simultaneously be a space of appropriation and exploitation that fetishizes the folk (Babcock 1995). Addressing some of these neocolonial concerns, Kimberley Lau's New Age Capitalism turns the folkloric lens fully onto the consumer (2000). Lau explores how the consumer might constitute their act of consumption as a conscious participation in a folk tradition, a tradition often quite distant from the consumer's own folk culture. Notably, Kapchan and Lau move the discussion of folklore and economics into the global present, drawing on postcolonial and neocolonial theory, and back into macroeconomics. 
This last trajectory moves the discussion of folklore and economics into the space of the marketplace itself, defining that space as both a contact zone and generative, one that draws on, creates a venue for, and produces folklore. This approach points to the complexities of the social relationships at work in the marketplace. As Pratt has said of the contact zone, these are the "social spaces where cultures meet, clash, and grapple with each other" (1991, 34). Studying the marketplace has allowed folklorists to document the extent to which the folk are active agents in their economic lives, and the marketplace can serve as an important venue for the performance of folklore and the working out of cultural values. But looking at the marketplace also reveals the dangers of the power differentials at work and the commodification of a fuzzy "folkness" is a globalized capitalist society. To romanticize the marketplace, as Noyes warned, could be as dangerous an assumption as romanticizing the folk (1995).

As in economics itself, each of these trajectories has continued to hold sway and have value in the perspective it offers to the others. Further, these are not neat divisions. Rather, the history of folklore and economics has been one of rich discourse and nuanced complexity. These trajectories function here as the anchoring lines on a spider web: as each has been explored, it has pulled on the others, as each new study has added to the field, it has drawn connections between these lines, building a bigger and more complex web of discourse and understanding. Even Dorson eventually admitted the allure of a distinctive American folklore, while continuing to deride the mass-mediated "fakelore" often sold under that label (1959, [1977] 3-4).

Since the economic downturn of 2008, more folklore scholars have begun to interrogate the economics of the field and its subject matter, from a range of yantage points that show a distinct departure from earlier works. For example, in a presidential address to the Folklore society, Robert McDowell, assayed the role that folk beliefs played in bolstering the financial crisis of 2008. The belief in the infallibility of technology and mathematics, and financial beliefs about home buying ("the best investment anyone can make") and stock investments ("Buy whatever Warren Buffett is buying") represented a number of the unquestioned assumptions that led to the recession (2013). Alternatively, in her essay "Of Victims, Villains and Fairy Godmothers: Regnant Tales of Predatory Lending," Carolyn Grose (2009) analyzed stories that pushed against the default narrative of the victims of the subprime mortgage crisis as being irresponsible or unwitting. In "FairyTale Economics: Scarcity, Risk and Choice," Dorothy Noyes (2011) traced the changes and innovations in the structure of fairy tales in response to variances in socioeconomic opportunities available to the working classes. 
These newer studies have also drawn together the trajectories of folklore and economics, creating space for new approaches and intervening into some of the larger ongoing conversations in folklore studies itself. Some of the recent scholarship has sought to stretch the definition of folklore by viewing economic activity as a kind of "artistic practice" in itself. For example, Katherine Roberts (2012) deeply engages with the economics of landtenure and resource management as an adaptive strategy in rural Appalachia. Roberts's critique of place studies develops from Debra Lattanzi Shutika's, criticism that the legal and economic issues surrounding place have largely been ignored (2011, 409). Similarly, Timothy Austin (2012) describes theft as a folk practice in Mindanao, touching on how economic activity, or in this case the rejection of capitalist norms of exchange, may be encoded as both artistic and political folk production.

Other recent works explore the well-established tension between economic realities and the norms of social interaction. Greenhill and Magnusson (2010), for instance, probe the politics and polity of requesting cash wedding gifts. More subtly, John McDowell's work on narcocorridos, Mexican songs describing the narcotics trade and gang warfare, addresses how folklore can comment upon the ways in which economic structures shape communities (2012). Finally, William Ivey has probed the term "value" itself, with reference to divergent definitions of the term between folk groups, and how those definitions can affect how folklore is understood and used in public and governmental policy (2011). Ivey pairs the ideas of value and values, but in doing so subtly links and separates the economic and the ethical.

These three approaches to folklore and economics show not only the diversity of approach but also how folklorists interests have been honed from the macro to the micro to more holistic bridging of the two in their studies of the marketplace. Each approach provides perspective- the macro reveals the ontology of folklore and its relationship to class structures; the micro uncovers both the politics of commodification and the epistemology of that commodification as it relates to folklore; the marketplace lets us see how culture is produced, negotiated, and reproduced. At each level, meaning is made, power structures asserted and resisted, folklore and economics performed.

\section{WEAVING A WEB OF ECONOMICS AND FOLKLORE}

Whoever they are and however we define them, the folk live in a global world in which they are economic actors. This book aims to further the 
study of folklore and economics. The authors of the chapters invoke all three of the approaches mentioned above, but they also query each, and allow new intersections to emerge to fit the global and technologized world. In order to maintain a holistic approach, while the book is loosely organized along the same three trajectories-macro, micro, and value in the marketplace - the chapters also blur these divisions and create bridges between them. In particular, the difference here between macro and micro draws on but varies somewhat from traditional economics. In economic theory, macroeconomics deals with class structures but centers more on how national economies work, and microeconomics focuses on supply and demand, individual decision-making about resource allocation, and specific products within the marketplace. However, because folkłorists generally start with a narrower lens, what is macro to the folklorist- the economic functioning of a folk group-may count as micro to the economist. Here, then, the first chapters on the macro center on ideas of how the global and the local influence each other. The middle chapters take a more microapproach and look closely at how local groups navigate economic culture. The final chapters examine how folklore and economic activities are valued within folk groups. Themes centering on folklore as economic critique, performativity, commodification, and tourism weave through the chapters.

We have sought to include a multiplicity of disciplinary voices in the chapters that follow. By their very nature, folklore and economics lie at the nexus of disciplines, pulling together ideas, vocabulary, and practices from both and weaving them into a whole cloth. While we, as editors, and this introduction are firmly situated in folklore, we are pleased to include voices from business studies, economics, and psychology. If we believe, as we deeply do, that folklorists have something of value to say about the economic world, then we must also embrace the idea that economists and other scholars may have something of value to say about the folkloristic one. Above all, we hope that this work will serve as a testament to disciplinary diplomacy in the name of deeper conversations and stronger humanistic research. Because the authors here write from multiple disciplinary perspectives and paradigms, they also do not conform to a single genre: some chapters follow typical ethnographic style; others include creative approaches and metacommentary; others take a more philosophical tack. All are engaged in a discussion of how we culturally make meaning of ourselves as economic beings, through consumption and labor and through folklore, and what our folklore says about how we view these transactions. All start from an assumption that the folk are actively and thoughtfully engaged in the economy. 
The first five chapters explore the economic relationship between the global and the local. Historically, the local has been the purview of folklore, what sets it apart from broader fields like cultural studies. In the global economy, however, the local is often already global in ways that can prove dynamic and productive. Further, this relationship works in both directions - a folk group may utilize globally sourced materials to produce a uniquely local product, and they may find their local product and its connection to a specific folk have value on the global market. In that larger market, folk culture can become a form of cultural sustainability and resistance against the pressures of globalization itself. The authors that begin this book, then, lay bare the assumption that the global and the local are necessarily a binary or that one can be separated easily from the other:

The first two chapters examine the ways in which the global is imbricated in the local and vice versa. In his chapter, 1 , on Louisiana's crawfish boats, John Laudun reveals how folkloric forms have always incorporated elements from around the world, while responding to highly localized pressures and traditions. While in the Italian quarries and workshops that Amy Shuman describes in chapter 12, the local objects become globalized, the crawfish boats are local objects made of globally sourced materials and enmeshed in global economies of exchange. Laudun points to how the folklorists' paradigm has tended to guide them to focus on the locally contextualized object but not necessarily the global context that helped create it. Julie M-A. LeBlanc's work, chapter 2, reverses this flow from the local to the global. LeBlanc explores how brewer Unibroue's references to Québécois folktales on its labels have helped to safeguard a sense of local identification and pride even as the company moved into the global marketplace and was purchasêd by a larger, multinational corporation. Yet these symbols are read differently by different generations of Québécois, forcing a renegotiation of Québec's history and culture between not only emic and etic consumers but also members of the group.

Chapters 3, 4, and 5 continue to examine how local cultures are contextualized and valued as they are made available for consumption by outsiders. As folklore is commodified for outside audiences, folk groups may seek ways to express and sustain their own identities. The authors of these chapters move beyond tourism to consider how such identities can be honed and articulated in the global marketplace. In each of these chapters, local practices launched into a larger context help sustain culture, but in doing so they show how the location of cultural identification can shift. Academic critiques of offering culture as a commodity have centered on how those representations can be highly problematic depending on who is doing the commodification of 
what, how, and to what ends (cf. Barbara Kirshenblatt-Gimblett 1998; John Clifford 1997). However, such an assessment becomes more complicated when that cultural commodity has become a cornerstone of self-identity or the commodification is coming from within the community.

In chapter 3, James I. Deutsch and Halle M. Butvin move from the commercial to the cultural marketplace. Their chapter focuses on the role of the folklorist to address the competing needs and desires that arise between institutions, organizers, artisans, and the public in the touristic space, in particular during the Smithsonian's annual Folklife Festival on the National Mall. Here, labor itself can become "an object of touristic curiosity" (MacCannell [1976] 1989, 6). During the festival, traditional artisans' labor is the focus of the visitors' gaze, while the products that labor produces, sold in the Festival Marketplace, risk becoming detached from their producers. As Deutsch and Butvin describe, organizers and artisans must work in concert to keep the products for sale in the separate Festival Marketplace culturally contextualized and socially responsible within a festival and tourist environment.

Michael Lange's chapter 4 and Cristofer Johnson's chapter 5 suggest that while a culture-based origin story may add monetary value to a local product in the global marketplace, the value for the community may be in cultural sustainability. Lange describes how maple producers, who have historically sold their product using cultural iconography, may question whether they are selling Vermont or selling syrup and the ramifications of each. Faced with global reach, some of the Vermont identification is being dropped but the practices and group experience of producing maple remain strong. Where then is the traditional folklore located in the global marketing of maple? Focusing on the Orkney Islands, Johnson explores how some fishermen have similarly drawn on cultural knowledge to help maintain their livelihoods but transitioned their skills into running a fish hatchery. While the materiality of much of the fishermen's work remains the same, consisting of their interactions with the fish and sea, the hatchery requires a different kind of interaction between groups' members. As a result, the project has brought together diverse and historically at-odds groups within the islands. Set against the larger backdrop of the European Union, the hatchery becomes a source of pride, as it helps reclaim power and sustain the people both culturally and economically.

Lange's, Johnson's, and Cassie Patterson's chapters bridge between macrolevel concerns of global economies and local cultures and microlevel explorations of individual group responses to economic pressures. Turning more toward the micro, chapters 6 through 10 examine how folk 
groups - including towns, artists and artisans, and local communities - weigh choices within their economic and cultural lives, and use both economics and folklore as forms of resistance against economic structures. Cassie Patterson's chapter, 6, deals with the commodification of culture itself within the sphere of tourism, interrogating the economic and ethical stakes of displaying public heritage for outside consumption. Patterson delves into moral geographies, nonmonetary markets, and the economics of attention. Through ethnography, she analyzes a new set of murals in the town of Portsmouth, Ohio, and the tourism they have drawn. For Patterson, this discussion raises questions of the moral responsibilities of citizens to produce and promote public heritage and the usefulness of such cultural display as a mediation between the town and the world at largê.

Bringing the lens even further in, Zhao Yuanhao and Puja BatraWells consider how individuals interact economically in their daily lives and make those lives and relationships work. In chapter 7, Zhao examines the deep structure and generative possibilities of a highly localized folk economy. Zhao's ethnography of a Hui marketplace in northern China proposes a quotidian and chaotic space of exchange, thus departing from the Bakhtinian carnivalesque market notable forits exceptionalism and liminality. While the Hui market may seem chaotic, the disorder belies a constantly negotiated order between government and people, different ethnic and religious groups, and individuals. The marketplace thus demonstrates economics and folklore in a conceptual and practical contact zone. BatraWells, in chapter 8 , investigates the strategies visual artists use to monetize their artworks that must take into account valuations of their labor, their socially expected role as bohemians, and analysis of the influences of the art market and economy. Folklore's vernacular lens exposes how this group of artists both make and make do within their daily lives.

While the preceding chapters have shown folk groups utilizing the marketplace to preserve their livelihoods, such engagement in the marketplace can present challenges for groups who have chosen to identify themselves in opposition to it. The intentional community of Twin Oaks is also deeply and actively engaged in capitalism for their survival, an economic system to which they also stand in stated opposition (chapter 9). Writing in the tradition of critical folklore studies but from a business perspective, Rahima Schwenkbeck details the community's ambivalence regarding their own business practices. Built on utopian principles that eschew capitalism, Twin Oaks nonetheless became extremely successful making and selling hammocks, forcing the community to negotiate their relationships and positionality with each other, their labor, and the larger society and economy. 
Schwenkbeck calls into question what happens when a community becomes victims of their own economic success and must weigh community and personal needs against the ideology by which they hope to live. Resistance to economic structures, however, can be overt or subtle.

While the artisan hammock makers feel the tension of needing to participate in the economy, Irene Sotiropoulou, in chapter 10, examines a community's use of folktales as critical commentary on the economy and mainstream economic values. Sotiropoulou uses a close reading of the Cretan tale "Why the Sea Is Salty" to describe an instance of how a folk group has chosen to define its own economics outside of or in opposition to mainstream capitalist ideas. Sotiropoulou looks to folktales, long analyzed in terms of the psychological and social content, to understand grassroots economics. Writing from a post-Marxist perspective and beginning with an autoethnography that exposes the Western and middle-class biases of economic study, Sotiropoulou argues for an economically savvy lower class who deploys folktales as a way to promote a more egalitarian system.

The previous chapters raise an important question: If capitalism, a system not without its faults, shapes the world economy at this juncture, then how do communities' values inform how they interact with and respond to capitalist structures and actions? How value is constructed and negotiated, what is valued and why, are the focus of the final chapters. Staying in cultural lore, William A. Ashton, in chapter 11, dives into the origin myth of Hermes and his dual role as trickster and god of the market. Ashton offers a psychological reading of the American corporate world through myth and archetype. Like studies in economic anthropology, such as Karen Ho's Liquidated (2009), Ashton turns an analytic lens on the American business community, In doing so, he offers a glimpse at the hegemonic economic values that the folk groups described in other chapters negotiate. Further, he raises the question of how the theories of folklore and deep analyses of the tropes of culture may guide, structure, or intervene in seemingly unrelated business practices. What, for instance, do the morals of folk tales and mythologies and the character of the trickster in particular, so often fixed in the making of bargains and the politics of exchange, offer us as we consider how we want our economy, both macro and micro, to work? What happens when we value the trickster in the economy?

Value, as Amy Shuman notes in chapter 12, can become a crucial metric in our attempts to understand the folk, folklore, and the marketplace. Shuman describes a group of artisans in the process of reassessing and reinterpreting the location of value-economic, material, cultural, knowledge-based, and environmental. Beginning with the artisans who quarry and work the marble 
of Pietrasanta, Italy, and the land through which they live, Shuman reveals how a folk economy incorporates a network of interrelated economies that work across several market levels and tie together several distinct technologies and folk groups in ways that challenge long-held academic distinctions between the modern and the traditional, the global and the local, art and craft.

If the previous chapters show how folklore and folk products can be discussed in economic terms, as both commodities and as critical interventions into capitalist systems, then we must ask anew where the folklorist fits, in these folkloric exchanges. Folklorists have long been acknowledging their roles as culture brokers, but how else may they be implicated in systems of exchange as active participants in the marketplace? Willow G. Mullins, in chapter 13 , considers the field of folklore's long investment in authenticity as a source of value. Reconsidering the metaphor of folklorist as culture broker in a globalized era of multicultural representation, Mullins suggests that if authenticity has become a commodity in itself, then folklorists may be among its most ardent consumers.

Folklore and economics have always been in conversation. That conversation, however, has often been dispersed. In an age of global media and global sourcing, folk arts online, and cultural sustainability, we see how our vernacular lives are intricately interwoven with the world economy. It may be more important than ever before to direct a folkloristic lens on economics and an economic one on folklore. Ultimately, we hope that this work will begin the creation of our own language of folklore and economics, a language we invite our readers to explore, to adapt, and to help remake, just as the folk in marketplace do.

\section{NOTES}

1. See the Multilingual Folk Tale Database: http://www.mftd.org/index.php?action=

2. Nineteenth-century Britain and the United States saw class as a highly structured system of social stratification, generally understood in terms of heredity-even in the nonaristocratic United States_-social position, education, employment, and economic wealth.

3. Such studies do exist, but are few and far between. For some good examples of research that does address the middle class, see Dorst (1989) and Hathaway (2005).

\section{REFERENCES}

Abrahams, Roger. 1993. After New Perspectives: Folklore Study in the Late Twentieth Century. Theorizing Folklore: Toward New Perspectives on the Politics of Culture, ed. Amy Shuman and Charles Briggs. Special issue, Western Folklore 52 (2/4): 379-400. Abrahams, Roger. n.d. “The Winking Gods of the Marketplace." Ms. 
American Economic Association. n.d. "What Is Economics?" American Economic Association. https://www.aeaweb.org/resources/students/what-is-economics. Appadurai, Arjun, ed. 1986. The Social Life of Things: Commodities in Cultural Perspective. Cambridge: Cambridge University Press.

Appadurai, Arjun, Frank Korom, and Margaret Mills. 1991. Gender, Genre, and Power in South Asian Expressive Traditions. Philadelphia: University of Pennsylvania Press.

Austin, Timothy. 2012. "Takers Keepers, Losers Weepers: Theft as Customary Play in the Southern Philippines." Journal of Folklore Research 49 (3): 347-69. https:/ / doi.org/10 .2979/jfolkrese.49.3.347.

Babcock, Barbara. 1995. "Marketing Maria: The Tribal Artist in the Age of Mechanical Reproduction.” In Looking High and Low: Art and Cultural Identity, ed. Brenda Jo Bright and Liza Bakewell. Tucson: University of Arizona Press.

Bakhtin, Mikhail. 1965. Rabelais and His World. Bloomington: University of Indiana Press.

Baron, Robert. 2010. "Sins of Objectification? Agency, Mediation, and Community Cultural Self-Determination in Public Folklore and Cultural Tourism Programming." Journal of American Folklore 123 (487): 63-91. https://doi.org/10.5406/jamerfolk.123 .487 .0063 .

Bauman, Richard. 1972. "Differential Identity and the Social Base of Folklore.' In Towards New Perspectives in Folklore, ed. Américo Paredes and Richard Bauman. Austin: University of Texas Press.

Bauman, Richard, and Américo Paredes. 1972. Towards New Perspectives in Folklore. Austin: University of Texas Press.

Becker, Jane. 1998. Selling Tradition: Appalachia and the Construction of the American Folk. Raleigh: University of North Carolina Press.

Behar, Ruth. 1993. Translated Woman: Crossing the Border with Esperanza's Story. Boston: Beacon.

Behar, Ruth, and Deborah A. Gordon. 1996. Women Writing Culture. Berkeley: University of California Press.

Ben-Amos, Dan. 1971. “Toward a Definition of Folklore in Context.” Journal of American Folklore 84 (331): 3-15. doi:10.2307/539729.

Bendix, Regina. 1997. In Search of Authenticity: The Formation of Folklore Studies. Madison: University of Wisconsin Press.

Bourdieu, Pierre. 1984. Distinction: A Social Critique of the Judgment of Taste. Abingdon, UK: Routledge Kegan and Paul.

Boutang, Yann Moulier. 2007. Cognitive Capitalism. Cambridge: Polity Press.

Briggs, Charles. 1980. The Woodcarvers of Cordova, New Mexico: Social Dimensions of an Artistic Revival. Knoxyille: University of Tennessee Press.

Bronner, Simon. 1985. Chain Carvers: Old Men Crafting Meaning. Lexington: University Press of Kentucky.

Brunvand, Jan. 1986. The Study of American Folklore: An Introduction. New York: W. W. Norton \& Co.

Cantwell, Robert. 1993. Ethnomimesis: Folklife and the Representation of Culture. Chapel Hill: University of North Carolina Press.

Crehan, Kate. 2016. Gramsci's Common Sense: Inequality and Its Narratives. Durham, NC: Duke University Press.

Clifford, James. 1988. The Predicament of Culture: Twentieth-Century Ethnography, Literature, and Art. Cambridge, MA: Harvard University.

Clifford, James. 1997. Routes. Cambridge, MA: Harvard University Press.

Clifford, James, and George E. Marcus. 1986. Writing Culture: The Politics and Poetics of Ethnography. Berkeley: University of California Press. 
de Certeau, Michel. 1984. The Practice of Everyday Life. Berkeley: University of California Press. Dorson, Richard. [1959] 1977. American Folklore. Chicago: University of Chicago Press. Dorson, Richard. 1976. Folklore and Fakelore. Cambridge, MA: Harvard University Press. Dorst, John. 1989. The Written Suburb: An American Site, An Ethnographic Dilemma.

Philadelphia: University of Pennsylvania Press.

Dundes, Alan. 1980. Interpreting Folk.lore. 12th ed. Bloomington: Indiana University Press.

Ehrenreich, Barbara. 2001. Nickel and Dimed: On (Not) Getting by in America. New York: Henry Holt Owl Books.

Gencarella, Stephen Olbrys. 2011. "Folk Criticism and the Art of Critical Folklore Studies." Journal of American Folklore 124 (494): 251-71. https://doi.org/10.5406 /jamerfolk.124.494.0251.

Glassie, Henry. 1968. Pattern in the Material Folk Culture of the Eastern United States. Philadelphia: University of Pennsylvania Press.

Graburn, Nelson H. H. 1976. Ethnic and Tourist Arts: Cultural Expressions from the Fourth World. Berkeley: University of California Press.

Gramsci, Antonio. 1985. “Osservazioni sul folklore.” In Quaderni dal carcere. Vol. 3. Turin: Einaudi.

Green, Archie. 1971. Only a Miner: Studies in Recorded Coal Mining Songs. Urbana: University of Illinois Press.

Green, Archie. 1978. "Industrial Lore: A Bibliographic-Semantic Query.” In Working Americans: Contemporary Approaches to Occupational Folklife, ed. Robert H. Byington.

Smithsonian Folklife Studies No. 3. Washington, DC: Smithsonian Institution Press.

Green, Archie. 1993. Wobblies, Pile Butts and Other Heroes: Laborlore Explorations. Urbana: University of Illinois Press.

Green, Archie. 2002. Tin Men. Urbana: University of Illinois Press.

Green, Thomas, ed. 1997. Folklore: An Encyclopedia of Beliefs, Customs, Tales, Music, and Art. Vol. 1. Santa Barbara, CA: ABC-CLIO Information Services.

Greenhill, Pauline, and K. Magnusson. 2010. "Your Presence at Our Wedding Is Present Enough': Lies, Coding, Maintaining Personal Face, and the Cash Gift.” Journal of Folklore Research 47 (3): 307-33.

Grose, Carolyn. 2009. "Of Victims, Villains and Fairy Godmothers: Regnant Tales of Predatory Lending." NYLS Clinical Research Institute Paper No. 08/09 \#20. Available at SSRN: https://sstn.com/abstract=1412784.

Guss, David. 2001. The Festive State: Race, Ethnicity, and Nationalism as Cultural Performance. Berkeley: University of California Press.

Hathaway, Rosemary V. 2005. "'Life in the TV': The Visual Nature of 9/11 Lore and Its Impact on Vernacular Response." Journal of Folklore Research 42 (1): 33-56.

Hemmersam, Fleming. 1985. "Worker Lore and Labor Lore." ARV: Scandinavian Yearbook of Folklore 41: 17-29.

Ho, Karen. 2009. Liquidated: An Ethnography of Wall Street. Durham, NC: Duke University Press.

Honko, Lauri. 1988. "Studies on Tradition and Cultural Identity: An Introduction." In Tradition and Cultural Identity, ed. Lauri Honko. Turku, Finland: Nordic Institute of Folklore.

Hufford, Mary, ed. 1994. Conserving Culture: A New Discourse on Heritage. Urbana: University of Illinois Press.

Huyssen, Andreas. 1995. Twilight Memories: Marking Time in a Culture of Amnesia. New York: Routledge.

Hymes, Dell. 2003. Now I Know Only So Far: Essays in Ethnopoetics. Lincoln: University of Nebraska Press.

Ingram, Shelley, Willow G. Mullins, and Todd Richardson. 2019. Implied Nowhere: Absence in Folklore Studies. Jackson: University of Mississippi Press. 
Ivey, Bill. 2011. "Values and Value in Folklore (AFS Presidential Plenary Address, 2007)."

The Journal of American Folklore 124 (491): 6-18. doi:10.5406/jamerfolk.124.491.0006.

Johnson, Paula, ed. 1988. Working the Water: The Commercial Fisheries of Maryland's Pautuxent

River. Charlottesville: Calvert Marine Museum and University Press of Virginia.

Jones, Michael Owen. 1975. The Handmade Object and Its Maker. Berkeley: University of California Press.

Jones, Michael Owen. 1984. "Introduction: Works of Art, Art as Work, and the Arts of Working.” Western Folklore 43 (3): 172-78.

Kapchan, Deborah. [1996] 2010. Gender on the Marketplace: Moroccan Women and the Revoicing of Tradition. Philadelphia: University of Pennsylvania Press.

Karp, Ivan. 1991. Exbibiting Cultures: The Politics and Poetics of Museum Display. Washington, DC: Smithsonian.

Kirshenblatt-Gimblett, Barbara. 1989. "Objects of Memory: Material Culture as Life Review.” In Folk Groups and Folklore Genres: A Reader, ed. Elliott Oring. Logan: Utah State University Press.

Kirshenblatt-Gimblett, Barbara. 1998. Destination Culture: Tourism, Museums, and Heritage. Berkeley: University of California Press.

Koch, Gertraud. 2012. "Work and Professions." In A Companion to Folklore, ed. Regina Bendix and Galit Hasan-Rokem. Chichester, UK: Wiley Blackwell. https://doi.org /10.1002/9781118379936.

Korom, Frank. 1999. "Empowerment through Representation and Collaboration in Museum Exhibitions." Journal of Folklore Research 36 (2-3): 235-41.

Korson, George. 1927. Songs and Ballads of the Anthracite Miners. New York: Grafton Press.

Korson, George. 1938. Minstrels of the Mine Patch. Philadelphia: University of Pennsylvania Press.

Kurin, Richard. 1997. Reflections of a Culture Broker: A View from the Smithsonian. Washington, DC: Smithsonian Institution.

Lang, Andrew. 2015. "Modern Mythology." In The Selected Works of Andrew Lang. Vol. 1: Anthropology: Fairy Tale, Folklore, the Origins of Religion, Psychical Research, ed. Andrew Teverson, Alex Warwick, and Leigh Wilson. Edinburgh: Edinburgh University Press.

Lau, Kimberly J. 2000. New Age Capitalism: Making Money East of Eden. Philadelphia: University of Pénnsylvania

Lee, Tong Soon. 2009. Chinese Street Opera in Singapore. Urbana: University of Illinois Press. Limón, José. 1983. "Western Marxism and Folklore: A Critical Introduction." Journal of American Folklore 96 (379): 34-52.

Limón, José. 2012. Américo Paredes: Culture and Critique. Austin: University of Texas Press.

MacCannell, Dean. [1989] 1976. The Tourist: A New Theory of the Leisure Class. New York: Schocken Books.

Maurer, Bill. 2006. "In the Matter of Marxism.” In Handbook of Material Culture, ed. Chris Tilley, Webb Keane et al. London: Sage.

McCarl, Robert S. 1996. “Occupational Folklore.” In American Folklore: An Encyclopedia, ed. J. H. Brunvard. New York: Garland.

McCarl, Robert S. 1997. "Occupational Folklore.” In Folklore: An Encyclopedia of Beliefs, Customs, Tales, Music and Art, ed. Thomas Green. Santa Barbara: ABC-CIIO.

McDowell, John. 2012. “The Ballad of Narcomexico." Journal of Folklore Research 49 (3): 249-74.

McDowall, Robert. 2013. “The Folklore of Finance.” Folklore 124 (3): 253-64.

McRobbie, Angela. 2004. "Making a Living as a Visual Artist in London's Small Scale Creative Economy." In Cultural Industries and the Production of Culture, ed. D. Power and A. J. Scott. New York: Routledge. 
Miller, Daniel. 2006. “Consumption.” In Handbook of Material Culture, ed. Chris Tilley, Webb Keane, et al. London: Sage.

Naumann, Hans. 1921. Primitive Gemeinschaftskultur. Jena, Germany: Diederich.

Newell, William. 1888. "On the Field and Work of a Journal of American Folk-Lore." The Journal of American Folklore 1 (1): 3-7. http://www.jstor.org/stable/532881.

Nickerson, Bruce. 1974. "Is There a Folk in the Factory?" Journal of American Folklore 87 (344): 133-39.

Noyes, Dorothy. 1995. "Group." In "Common Ground: Keywords for the Study of Expressive Culture." Journal of American Folklore 108 (430): 449-78.

Noyes, Dorothy. 2011. "Fairy-Tale Economics: Scarcity, Risk and Choice.” Lecture, Western Michigan University, March 17.

Noyes, Dorothy. 2015. "From Cultural Forms to Policy Objects: Comparison in Scholarship and Policy." Journal of Folklore Research 52 (2-3): 299-313. https://doi .org/10.2979/jfolkrese.52.2-3.299.

Paredes, Américo. 1970. Folktales of Mexico. Chicago: University of Chicago Press.

Prahlad, Anand. 1999. "Guess Who's Coming to Dinner: Folklore, Folkloristics, and African American Literary Criticism.” African American Reviem 33 (4): $565-75$.

Pratt, Mary Louise. 1991. "Arts of the Contact Zone.” Profession: 33-40. JSTOR 25595469.

Roberts, Katherine. 2012. "The Art of Staying Put: Managing Land and Minerals in Rural America." Journal of American Folklore 126 (502): 407-33.

Rosaldo, Renato. 1989. Culture and Truth: The Remaking of Sacial Analysis. Boston: Beacon Press.

Ross, Andrew. 2010. Nice Work, if You Can Get it: Life and Labop in Precarious Times. New York: New York University Press.

Said, Edward. 1979. Orientalism. New York: Vintage Books.

Santino, Jack. 1990. "The Outlaw Emotions: Narrative Expressions on the Rules and Roles of Occupational Identity." American Behavioral Scientist 33 (3): 318-29.

Sennett, Richard. 2006. The Culture of New Capitalism. New Haven, CT: Yale University Press.

Sheumaker, Helen, and Shirley Teresa Wajda. 2008. Material Culture in America: Understanding Everyday Life. Santa Barbara: ABC-CLIO.

Shutika, Debra Lattanzi. 2011. Beyond the Borderlands: Migration and Belonging in the United States and Mexico. Berkeley: University of California Press.

Sommers, Laurie Kay. 1995. "Definitions of 'Folk' and 'Lore' in the Smithsonian Festival of American Folklife." Journal of Folklore Research 33: 227-31.

Tangherlini, Timothy. 1997. "Marxist Approach." In Folklore: An Encyclopedia of Beliefs, Customs, Tales, Music and Art, ed. Thomas Green. Santa Barbara: ABC-CIIO.

Toelken, Barre. 1995. "Fieldwork Enlightenment." Parabola: The Magazine of Myth and Tradition 20: 28-35.

Urry, John. 1990. The Tourist Gaze. London: SAGE.

Visweswaran, Kamala. 1994. Fictions of Feminist Ethnography. Minneapolis: University of Minnesota Press.

Vlach, John. 1991. By the Work of Their Hands: Studies in Afro-American Folklife. Charlottesville: University of Virginia Press.

Vlach, John, and Dell Upton. 1986. Common Places: Readings in American Vernacular Architecture. Athens: University of Georgia Press.

Zinn, Howard. 2015. A People's History of the United States. New York: Harper Perennial Modern Classics.

Zipes, Jack. 1979. Breaking the Magic Spell: Radical Theories of Folk and Fairy Tales. Austin: University of Texas Press. 